\title{
Lembranças de Alunos, Imagens de Professores: Narrativas e Diálogos sobre Formação Médica
}

\author{
Memories of Students, Images of Teachers: \\ Narratives and Dialogues About Medical \\ Education
}

Lenina Lopes Soares Silva

\begin{abstract}
RESUMO
Trata-se de uma incursão histórica pelo pensamento e pelo ensino médico, discutindo-se a formação médica de forma contextualizada, com o objetivo de compreendê-la para interpretála através de lembranças de alunos. Enfoca-se a mediação pedagógica dessa formação visando promover o diálogo entre a história social da Medicina e as memórias de alunos, situando-as no contexto histórico-social e cultural, ao mesmo tempo em que, busca-se apreender as imagens dos professores que deixaram marcas significativas para as vidas dos alunos, em termos profissionais, sociais e culturais. Configura-se assim, uma memória da formação médica da Faculdade de Medicina da Universidade Federal do Rio Grande do Norte (UFRN), desde a criação em 1955, como Faculdade de Medicina de Natal, até 1963, como Faculdade de Medicina da UFRN. As lembranças foram colhidas mediante entrevistas temáticas com alunos egressos das três primeiras turmas concluintes, dos anos de 1961, 1962 e 1963, da referida Faculdade e interpretadas utilizando-se a cartografia como técnica que envolve a construção de quadros interpretativos, tendo como unidade de análise as palavras representativas dos elementos constituintes da mediação pedagógica, extraídas das narrativas dos sujeitos, que carregam também as imagens dos professores que compõem o aventado diálogo, por suas contribuições para a existência do saber e do fazer da educação médica em Natal/RN. Compreende-se que essa Faculdade foi criada num momento histórico-social e cultural em que o Brasil e o mundo ainda tentavam encontrar novos caminhos, após as turbulências causadas pela Segunda Guerra Mundial, e a intelectualidade natalense visualizava o enquadramento da cidade nos parâmetros da modernidade. O currículo implantado era técnico/racional, mas, ao ser interpretado pela ação, através da reconstrução das lembranças dos alunos, nos vestígios da mediação pedagógica da formação médica e nas imagens dos professores ainda vivificadas nas memórias, torna-se possível entender que a esses alunos foi ensinado: um saber relacional que permitia o diálogo, a transmissão da experiência e o compromisso médico voltado para o atendimento à população em primeiro lugar, ao mesmo tempo em que fomentava sentimentos e desejos de ajudar ao próximo, sendo os próprios professores o exemplo disso, conformando-se, assim, com um saber contextual, a par de uma participação política e de responsabilidade ética para com a sociedade.
\end{abstract}

Orientador: Professor Dr. José Willington Germano 


\section{Defesa de Dissertação de Mestrado}

Programa de Pós-Graduação em Ciências Sociais, Base de Pesquisa Cultura, Política e Educação, Universidade Federal do Rio Grande do Norte, em 27 de abril de 2006.

\section{Disponível para consulta}

Biblioteca Central Zila Mamede da Universidade Federal do Rio Grande do Norte (UFRN) e na Biblioteca do Curso de Medicina da UFRN, em Natal/RN.

\section{Endereço para correspondência}

Lenina Lopes Soares Silva

Rua Professora Dirce Coutinho, 1873

Condomínio Grand Slam - Capim Macio 59082-180 - Natal - Rio Grande do Norte

E-mail: lanier@digi.com.br 